\title{
Water Loss and Morphological Modifications in Leaves during Acclimatization of Cork Oak Micropropagated Plantlets
}

\author{
Anabela Romano \\ Faculdade de Engenharia de Recursos Naturais \\ Universidade do Algarve \\ Campus de Gambelas \\ 8005-139 Faro, Portugal \\ aromano@ualg.pt
}

\author{
M.A. Martins-Loução \\ Faculdade de Ciências \\ Universidade de Lisboa \\ Campo Grande, Bloco C2, Piso 4 \\ 1749-016 Lisboa, Portugal
}

Keywords: Leaf anatomy, Quercus suber L., water stress

\begin{abstract}
This study characterises some aspects of foliar anatomy of cork oak micropropagated plantlets, and rates of water loss by different types of leaves during the acclimatization period. Water loss from leaves of in vitro cultured plantlets was much higher than that of acclimatized plants or seedlings. Leaves from in vitro plantlets lost $53 \%$ of their water within the first 30 min under water stress conditions, while leaves from acclimatized plants lost $14 \%$. Leaves of in vitro grown plants presented open stomata and collapsed guard cells, while acclimatized leaves presented closed stomata. Shade-leaf structure was observed in transverse sections of in vitro leaves, with large intercellular air spaces and a low mesophyll cell density, but with a differentiated palisade cell layer. Leaves from acclimatized plants showed a sun-leaf structure with small intercellular air spaces, high cell density and two or three palisade cell layers. During acclimatization leaf thickness increased, as well as cell compactness and differentiation. Stomatal density, stomatal aperture and guard cell protuberance decreased during the acclimatization period, while trichome density increased.
\end{abstract}

\section{INTRODUCTION}

The transfer of plantlets from in vitro conditions to the glasshouse is still problematic for many species, especially woody plants. The main cause of plant mortality during acclimatization is water stress. This results from excessive transpiration from leaves, stomata and cuticle, or from inadequate uptake of water from roots. Various authors have related water loss to abnormal stomata (Donnelly et al., 1985; Blanke and Belcher, 1989; Santamaria et al., 1993). Others related this water loss to reduced thickness and/or anomalous structure of the cuticle (Dhawan and Bhojwani, 1987; Capellades et al., 1990; Diettrich et al., 1992). Anomalous structure of the leaves, altered stomata density and reduced trichome density, are other factors causing water stress during acclimatization (Donnelly et al., 1985; Lee et al., 1988; Capellades et al., 1990). The goal of this work was to study leaf anatomy and water loss during in vitro acclimatization of cork oak micropropagated plantlets.

\section{MATERIALS AND METHODS}

\section{Plant Material and Growing Conditions}

The procedures and conditions for establishment, proliferation and rooting of shoot cultures, starting from buds of cork oak adult trees, have been described previously (Romano et al., 1992). For rooting, the basal ends of individual shoots $3 \mathrm{~cm}$ in length were dipped for $2 \mathrm{~min}$ in $2.5 \mathrm{M}$ indole-3-butyric (IBA) acid followed by culture on Gressoff and Doy (1972) growth regulator-free medium. Four weeks after root induction, plantlets were washed to remove agar and planted into a mixture of peat and perlite $(3: 1)$. Plantlets were placed in an acclimatization chamber (Aralab 500 E) set at 90-95\% relative humidity, a temperature of $25 \pm 2^{\circ} \mathrm{C}$, and a $16 \mathrm{~h}$ photoperiod $\left(100 \mu \mathrm{mol} \mathrm{m} \mathrm{m}^{-2}\right)$ for four weeks and then placed under glasshouse conditions. 


\section{Comparative Water Loss Analysis}

Water loss was studied in six different types of leaves: i) leaves from in vitro grown plantlets at the end of the rooting phase; ii) persistent leaves from 1-month-old acclimatized plants; iii) new leaves from 1-month-old acclimatized plants; iv) new leaves from 6-month-old acclimatized plants; v) leaves from 3-year-old micropropagated plants, and vi) leaves from 3-year-old seedlings, the latter two growing in the field. The leaves were excised and immersed in distilled water (to ensure full leaf turgidity) and kept at $25^{\circ} \mathrm{C}$ in diffuse light. After $3 \mathrm{~h}$ under these conditions their surfaces were gently blotted, and they were placed in shallow aluminium cups with the abaxial surface facing up. Water loss from each leaf was estimated by loss of weight. Fresh weight (FW) was taken every $10 \mathrm{~min}$, for the first hour and every $20 \mathrm{~min}$ thereafter, for a total period of $160 \mathrm{~min}$. The temperature $\left(21 \pm 2^{\circ} \mathrm{C}\right)$ and relative humidity $(50 \%)$ did not vary appreciably throughout the experiment. After these measurements, the dry weight (DW) of the leaves was determined after oven drying at $80^{\circ} \mathrm{C}$ for $24 \mathrm{~h}$. Relative water content (RWC) was estimated at time (t) as follows: RCW $(\%)=\left[\left(\mathrm{FW}_{\mathrm{t}}-\mathrm{DW}\right) /\left(\mathrm{FW}_{\mathrm{s}}-\mathrm{DW}\right)\right] \times 100$, where $\mathrm{FW}_{\mathrm{t}}$ is the fresh weight at time $\mathrm{t}, \mathrm{FW}_{\mathrm{s}}$ is the initial fresh weight of saturated leaf, and DW is the dry weight. Each sample consisted of a fully developed leaf. For in vitro plantlets groups of four leaves were used to reduce errors of small sample size. The experiment was repeated once and each set consisted of five replicates.

\section{Anatomical and Histochemical Studies}

Leaf pieces were fixed in a mixture of 3:1:1 ethanol:acetic acid:formalin for $48 \mathrm{~h}$, dehydrated in a graded ethanol series and embedded in glycol methacrylate. Sections (6 $\mu \mathrm{m})$ were prepared and stained in toluidine blue $(0.05 \%$, w/v). For scanning electron microscopy (SEM), leaf pieces were fixed and dehydrated as before and critical point dried in a Denton DCP-1 Critical Point Dryer employing liquid $\mathrm{CO}_{2}$. Specimens were mounted on aluminium stubs, coated with gold-palladium (in a Polaron E 5300 Freeze Drier coupled with a Polaron E 5350) and observed with a JEOL JSM-T100 SEM.

\section{RESULTS AND DISCUSSION}

In a cork oak plantlet, three months after transfer to soil, different leaf types are distinguished: i) leaves grown under in vitro conditions, but persisting after acclimatization (persistent leaves); ii) leaves induced during in vitro culture, but developed after transfer to soil, which show intermediate characteristics (intermediate leaves); and iii) leaves differentiated in the glasshouse (new leaves). The rates of water loss observed for the different types of leaves are given in Fig 1. As expected, water loss by leaves from in vitro plantlets was much higher than that of acclimatized plants or seedlings (Fig. 1). Leaves from in vitro plantlets lost $53 \%$ of their water within the first 30 min of the dehydration treatment, while leaves from acclimatized plants lost $14 \%$ (Fig. 1). New leaves from plantlets after one month of acclimatization lost $14 \%$ water after 30 min of holding at $50 \%$ relative humidity at room temperature, compared to $29 \%$ from old leaves of 1-month-old plantlets. At the end of the dehydration period in vitro leaves presented open stomata and collapsed guard cells, while acclimatized leaves presented closed stomata (Table 1). Stomata of in vitro plantlets had raised, round guard cells compared to normal elliptical, sunken guard cells. Those stomata did not close under water stress conditions, while those of acclimatized plants were closed under these conditions. Stomata of a 1-month-old acclimatized plant had an intermediate response (Table 1). This might explain the poor control of water stress shown by these leaves (Ghashghaie et al., 1992; Santamaria et al., 1993). An increment on stomatal and trichome densities were observed during acclimatization process (Table 1). After 6 months of acclimatization the number of stomata per square millimetre was similar to what has been observed in the field (Molinas, 1991).

A shade-leaf structure (Molinas, 1991) was observed in transverse sections of in vitro leaves, with large intercellular air spaces and a low mesophyll cell density, but with a differentiated palisade cell layer (Table 1). These leaves generally die and only the new 
leaves resist acclimatization stress. New leaves from acclimatized plants showed a sunleaf structure with small intercellular air spaces, high cell density and two or three palisade cell layers (Table 1). The characteristics observed in in vitro leaves, persist in the first leaves developed ex vitro, the transition leaves. Vascular tissues of in vitro leaves were less developed and development increased during the acclimatization period (Table $1)$.

Morpho-physiological studies confirm the earlier reports that cultured plants have poor control of water loss (Dhawan et al., 1987; Diettrich et al., 1992; Ghashghaie et al., 1992). The results observed in this work suggest that the main factor causing death and slow recovery of micropropagated cork oak plantlets during the period of acclimatization is the poor control of water loss, until new leaves are developed. Protecting in vitro cultured plantlets from water stress by maintaining plantlets under high humidity over an interval of four weeks was found to be essential for successful acclimatization of cork oak micropropagated plantlets.

\section{Literature Cited}

Blanke, M.M. and Belcher, A.R. 1989. Stomata of apple leaves cultured in vitro. Plant Cell Tiss. Org. Cult. 19:85-89.

Capellades, M., Fontarnau, R., Carulla., C. and Debergh, P. 1990. Environment influences anatomy of stomata and epidermal cell in tissue-cultured Rosa multiflora. J. Amer. Soc. Hort. Sc. 115:141-145.

Dhawan, V. and Bhojwani, S.S. 1987. Hardening in vitro and morpho-physiological changes in the leaves during acclimatization of micropropagated plants of Leucaena leucocephala (Lam.) de Wit. Plant Sci. 53:65-72.

Diettrich, B., Mertinat, H. and Luckner, M. 1992. Reduction of water loss during ex vitro acclimatization of micropropagated Digitalis lanata clone plants. Biochem. Physiol. Pflanzen. 188:23-31.

Donnelly, D.J., Vidaver, W.E. and Lee, K. 1985. The anatomy of tissue-cultured red raspberry prior to and after transfer to soil. Plant Cell Tiss. Org. Cult. 4:43-50.

Ghashghaie, J., Brenckman, F. and Saugier, B. 1992. Water relations and growth of rose plants cultured in vitro under various relative humidities. Plant Cell Tiss. Org. Cult. 30:51-57.

Gresshoff, P.M. and Doy, C.H. 1972. Development and differentiation of haploid Lycopersicon esculentum (tomato). Planta. 170:161-170.

Lee, N., Wetzstein, H.Y. and Sommer, H.E. 1988. Quantum flux density effects on the anatomy and surface morphology of in vitro- and in vivo-developed sweetgum leaves. J. Amer. Soc. Hort. Sci. 113:167-171.

Molinas, M.L. 1991. The stomata of cork-oak, Quercus suber. An ultrastructural approach. Nord. J. Bot. 11:205-212.

Romano, A., Noronha, C. and Martins-Loução, M.A. 1992. Influence of growth regulators on shoot proliferation in Quercus suber L. Ann. Bot. 70:531-536.

Santamaria, J.M., Davies, W.J. and Atkinson, C.J. 1993. Stomata of micropropagated Delphinium plants respond to $\mathrm{ABA}, \mathrm{CO}_{2}$, light and water potential, but fail to close fully. J. Exp. Bot. 44:99-107. 


\section{$\underline{\text { Tables }}$}

Table 1. Features of leaf anatomy of cork oak plants at different acclimatization phases.

\begin{tabular}{lccc}
\hline & In vitro & Acclimatization & \\
\cline { 3 - 4 } & & 1 month (new leaves) & 6 months (new leaves) \\
\hline Epidermis & Thin, lacking cuticle & Thin with a thin cuticle & Thick, with cuticle \\
Palisade cell layers & 1 layer of loosely packed & 2 layers & 3 compact layers \\
Spongy & Spherical cells with large & Differentiated & Highly differentiated, \\
parenchyma & intercellular spaces & & small intercellular spaces \\
Vascular tissues & Less developed & Developed & Highly developed \\
Trichome & Rare & Few & Abundant \\
Stomatal density & 364 12 & $372 \pm 14$ & $456 \pm 17$ \\
Stomata & Abundant stomata,large & Guard cells with low & Few stomata with \\
& and raised guard cells & protuberance & depressed guard cells \\
Stomata response & None & Reduced & High \\
to water stress & & &
\end{tabular}

\section{Figures}

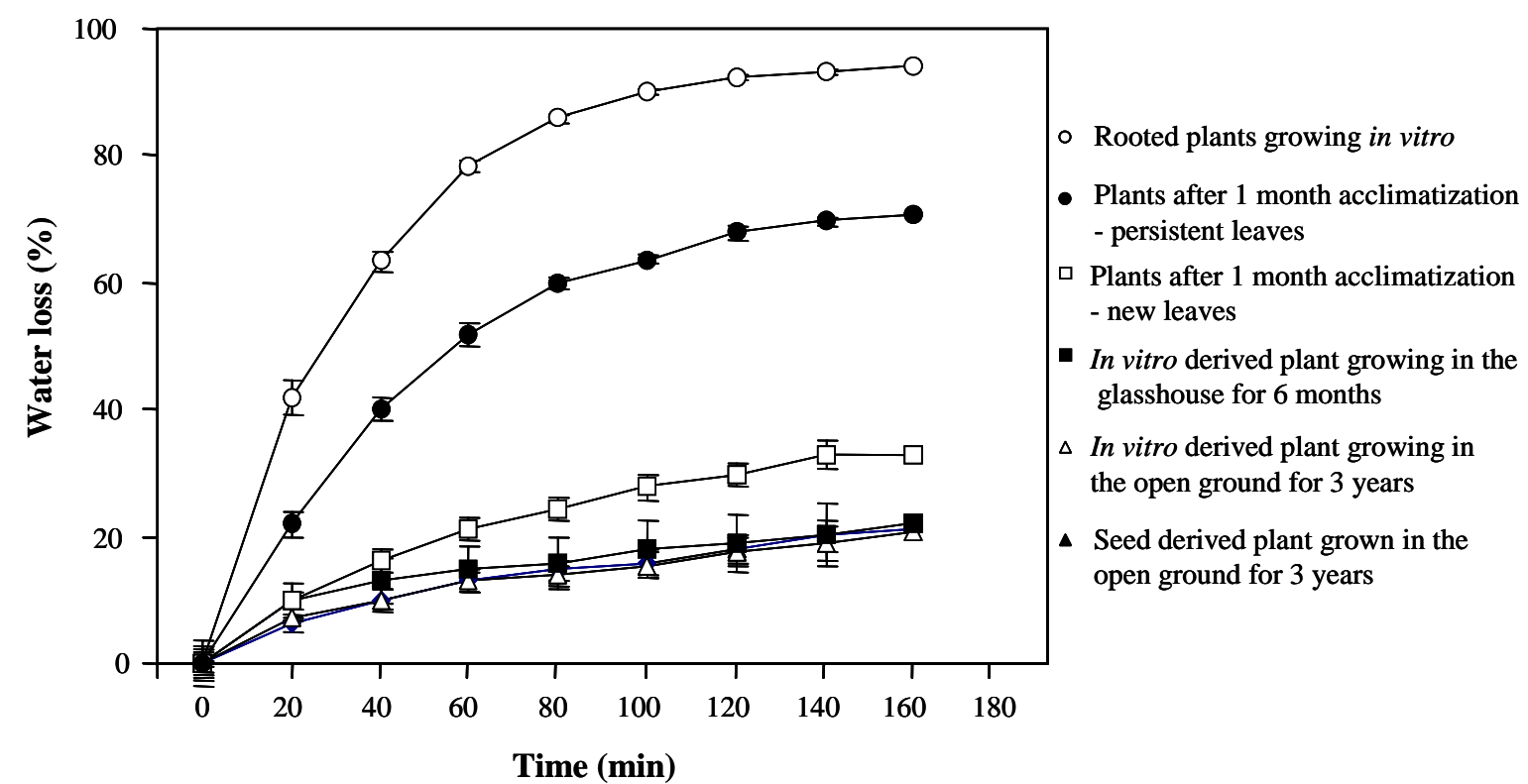

Fig. 1. Changes in relative water content of excised leaves (initially fully turgid) as a function of time. Each point represents the mean of 4 replicates (for details see text). 